\title{
Korszakváltás a krónikus C-vírus hepatitis terápiájában - új direkt ható antivirális szerek
}

\author{
Horváth Gábor dr. ${ }^{1,2}$ - Halász Tünde dr. ${ }^{3}$ \\ Makara Mihály dr. ${ }^{4}$ - Hunyady Béla dr. ${ }^{5,6}$ \\ ${ }^{1}$ Budai Hepatológiai Centrum, Budapest \\ ${ }^{2}$ Szent János Kórház és Észak-budai Egyesített Kórházak, Hepatológiai Szakambulancia, Budapest \\ ${ }^{3}$ Magyar Honvédség Egészségügyi Központ Honvédkórház, Patológiai Osztály, Budapest \\ ${ }^{4}$ Egyesített Szent István és Szent László Kórház, Budapest \\ ${ }^{5}$ Somogy Megyei Kaposi Mór Oktató Kórház, Belgyógyászati Osztály, Kaposvár \\ ${ }^{6}$ Pécsi Tudományegyetem, I. Belgyógyászati Klinika, Pécs
}

\begin{abstract}
A krónikus C-vírus hepatitis kezelés nélkül 15-25 év alatt májzsugort, májelégtelenséget, májrákot okozhat. A krónikus $\mathrm{C}$ hepatitis kezelésében túlzás nélkül forradalminak nevezhetó változást hozott a telaprevir és a boceprevir után a simeprevir, majd a második generációs direkt antivirális szerek, a nukleotidanalóg polimerázgátló sofosbuvir, az újabb proteázgátlók, az asunaprevir és a paritaprevir, az NS5A-gátlók, mint a daclatasvir, a ledipasvir és az ombitasvir, továbbá a nem nukleotidanalóg polimerázgátló, a dasabuvir elérhetővé válása. E készítmények kombinációival még a legnehezebben kezelhető betegcsoportokban is - a korábbi kezelésekhez képest rövidebb idő alatt és sokkal kevesebb mellékhatással - 90\% feletti gyógyulás érhető el. Kizárólag szakmai szempontokat figyelembe véve minden, hepatitis C-vírus-fertőzött beteg antivirális kezelése indokolt, és biztonságosságuk miatt valamennyi, kezelésre szoruló betegnél egyértelműen az interferonmentes kezelés az optimális. A szerzők áttekintik a legújabb kezelési lehetőségeket, amelyekkel már a hepatitis C-vírus teljes eradikációja sem utópia, ez azonban jól megtervezett, megszervezett szürőprogramok nélkül nem lehetséges. Orv. Hetil., 2015, 156(21), 841-848.
\end{abstract}

Kulcsszavak: krónikus C hepatitis, antivirális kezelés, direkt ható antivirális szerek

\section{New era in the treatment of chronic hepatitis $\mathrm{C}$ - novel direct acting antivirals}

Chronic hepatitis C, without treatment, can cause liver cirrhosis, liver failure and liver cancer. The availability of new oral direct acting antivirals, such as the protease inhibitors simeprevir, asunaprevir and paritaprevir, the NS5A inhibitors daclatasvir, ledipasvir, and ombitasvir, the polymerase inhibitors Sofosbuvir and dasabuvir have resulted an enormous progress in the treatment of chronic hepatitis C, leading to $>90 \%$ sustained viral response rates. Even the hardto-treat or previously treatment ineligible patients can be cured with the combination of these drugs. Furthermore the treatment duration is much shorter, and the side effects are minimal. Today, treatment of all hepatitis $\mathrm{C}$ virus infected patients is recommended, and the best choices are the interferon-free options. Eradication of hepatitis $\mathrm{C}$ virus has become realistic, however, appropriate screening programs are mandatory to achieve this goal.

Keywords: chronic hepatitis C, antiviral treatment, direct acting antivirals

Horváth, G., Halász, T., Makara, M., Hunyady, B. [New era in the treatment of chronic hepatitis C - novel direct acting antivirals]. Orv. Hetil., 2015, 156(21), 841-848.

(Beérkezett: 2015. március 25.; elfogadva: 2015. április 14.) 


\section{Rövidítések}

ABT3D = ombitasvir/paritaprevir/ritonavir + dasabuvir hármas kombináció; BMI = testtömeg- (body-mass) index; $\mathrm{CHC}=$ krónikus $\mathrm{C}$ hepatitis; $\mathrm{DAA}=$ direkt ható antivirális szer; $\mathrm{HCV}=$ hepatitis $\mathrm{C}$-vírus; IFN = interferon-alfa-2; $\mathrm{NA}=$ nukleoz $(\mathrm{t})$ idanalóg; peg-IFN = pegilált interferon-alfa- 2 ; $\mathrm{PI}=$ proteázgátló $\mathrm{RBV}=$ ribavirin $; \mathrm{SVR}=($ sustained viral response) tartós virológiai válasz

A hepatitis C-vírus (HCV) -fertőzés a betegek jelentős részénél a májban krónikus gyulladást okoz, amely kezelés nélkül 15-25 év alatt májzsugorhoz vezethet, és ebben a stádiumban már jelentősen nő a májrák kialakulásának a kockázata is. A betegség korai felismerése alapvető jelentőségû́ mind a beteg, mind a társadalom szempontjából. Az egyén számára a felismerés és az eredményes kezelés az egészség, a munkaképesség, az életminőség megőrzését jelenti, míg a közösség szempontjából a fertőzés terjedésének a megállítását, a későbbi súlyos szövődmények (májzsugor és következményei: varixvérzés, vascularis és parenchymás dekompenzáció, májtranszplantáció) megelőzését, és így jelentős egészségügyi költségmegtakarítást eredményezhet $[1,2]$.

Magyarországon 70000 före becsüljük a HCV-fertőzöttek számát, a betegek többsége nem is tud betegségéről [3]. Sajnálatos módon az újonnan felfedezett betegek közel fele a betegség felismerésekor már előrehaladott májbetegségben szenved, METAVIR F3-4 fibrosisstádiumban van.

A betegség kezelésére az 1990-es évek elején kezdtük alkalmazni az interferon- (IFN-) készítményeket (heti háromszor adott injekció formájában). A terápia idôtartamának növelésével, majd a ribavirin- (RBV-) tabletta hozzáadásával a gyógyulási arány (SVR) 5-10\%-ról 3040\%-ra nőtt. 2003-tól vált elérhetővé a pegilált interferon (peg-IFN, heti egyszeri injekció), amely RBV-vel kombinálva (kettôs kombináció) a korábban nem kezelt - úgynevezett naiv - betegek számára $40-50 \%$ gyógyulási esélyt adott a hazánkban leggyakoribb l-es genotípusú betegek kezelésekor. Problémát okozott, hogy ez a kombináció a korábban sikertelenül kezelt betegek esetében sokkal szerényebb (7-20\%) SVR-esélyt jelentett, továbbá mind a naiv, mind az újrakezelt betegek esetében számos negatív tényező - mint a májbetegség súlyossága (előrehaladott fibrosis, cirrhosis, májmúköodés dekompenzációja), életkor, rassz, nem, BMI, egyes kísérő betegségek, a beteg genetikai tényezői (IL-28B), a vírus genotípusa, a vírustiter - kedvezőtlenül befolyásolta a kezelésre adott választ, illetve a kezelés ellenjavallatát jelentette.

Jelentős előrelépést hozott a szájon át bevehető direkt ható antivirális szerek (DAA-k) terápiás palettára kerülése. A két első generációs proteázgátló (PI: boceprevir, telaprevir) 2011-ben került törzskönyvezésre. Ezek - a peg-IFN-nel és RBV-vel együtt adva („hármas kombináció") - bevezetésével a tartós vírusmentességi arány (SVR) 66-75\%-ra nőtt naiv betegek esetében. Továbbra is gondot jelentett, hogy előrehaladott májbetegségben és/vagy korábbi IFN-alapú kezelésre rosszul reagáló (kevéssé IFN-érzékeny) betegek gyógyulási aránya ennél lényegesen alacsonyabb maradt. Komoly hátránya e hármas kombinációknak, hogy a peg-IFN + RBV kezelésnél gyakoribb és súlyosabb mellékhatásokkal járnak, és ez fokozottan igaz azokra a súlyosabb, előrehaladott májbetegségben szenvedókre, akik esetében a leginkább indokolt és sürgető az antivirális kezelés $[4,5,6,7,8]$.

A CHC kezelésében túlzás nélkül forradalminak nevezhetô változás 2013-ban folytatódott a simeprevir, az első generációs PI-k második hullámának tekinthető készítmény, illetve a második generációs DAA-k első képviselőjének, a nukleotidanalóg (NA) polimerázgátló sofosbuvirnak a törzskönyvezésével. 2014-2015-ben további PI-k, mint az asunaprevir (csak Japánban) és a paritaprevir, NS5A-gátlók, mint a daclatasvir, a ledipasvir és az ombitasvir, és nem NA polimerázgátló, a dasabuvir került forgalomba. A DAA-k támadáspontjait, illetve a már törzskönyvezett és a még fejlesztés alatt álló készítményeket az 1. és 2. ábra mutatja [9].

Az első generációs DAA-k esetében a vírusrezisztenciával is komolyan számolnunk kellett, az újabb készítmények megfelelő kombinációi esetében ennek, úgy tűnik, kisebb a jelentősége. A kezelés megkezdése előtt meglevő rezisztens mutánsoknak érdemi negatív prediktív szerepe csak a simeprevir (la genotípus, Q80K-mutáns) és a daclatasvir (lb genotípus, NS5A-L31M/V és NS5AY93H polimorfizmus) esetében van.

A már törzskönyvezett készítmények alkalmazási előiratai szerint peg-IFN-nel és RBV-vel együtt adva vagy e készítmények nélkül, egymással kombinálva - úgynevezett IFN-mentes kombinációban - az eddigi kezelési módoknál lényegesen hatékonyabbak, rövidebb időtartamú kezelést tesznek lehetôvé, sokkal kevesebb mellékhatást okoznak, és olyan betegek számára is a gyógyulás esélyét nyújtják, akik IFN-alapú kezelést - ellenjavallat (például IFN-intolerancia, cytopenia vagy Child $B$ vagy $C$ stádiumú májcirrhosis stb.), vagy az IFN-alapú kezelési lehetőségek eredménytelensége miatt - nem kaphattak.

\section{Új kezelési lehetőségek a CHC terápiájában}

Hazánkban a betegek túlnyomó többsége (>90\%-a) a HCV l-es genotípusával, ezen belül is döntően az $\mathrm{lb}$ genotípussal fertózött [10], ezért a következókben elsősorban e betegcsoport kezelési lehetőségeit részletezzük. Az ettôl eltérő genotípussal fertőzött betegek kezelési lehetôségeit illető́n utalunk a nemzetközi és a hazai ajánlásokra $[1,11,12]$.

\section{IFN-t tartalmazó új kezelési lehetôségek $\mathrm{HCV}$ I-es genotípussal fertözött betegek esetén}

\section{Peg-IFN + RBV + sofosbuvir}

A NEUTRINO fázis III vizsgálatban az 1 -es genotípussal fertőzött, naiv betegek 12 hétig kaptak napi $1 \times 400$ mg sofosbuvirt peg-IFN-nel és RBV-vel kombinálva. 

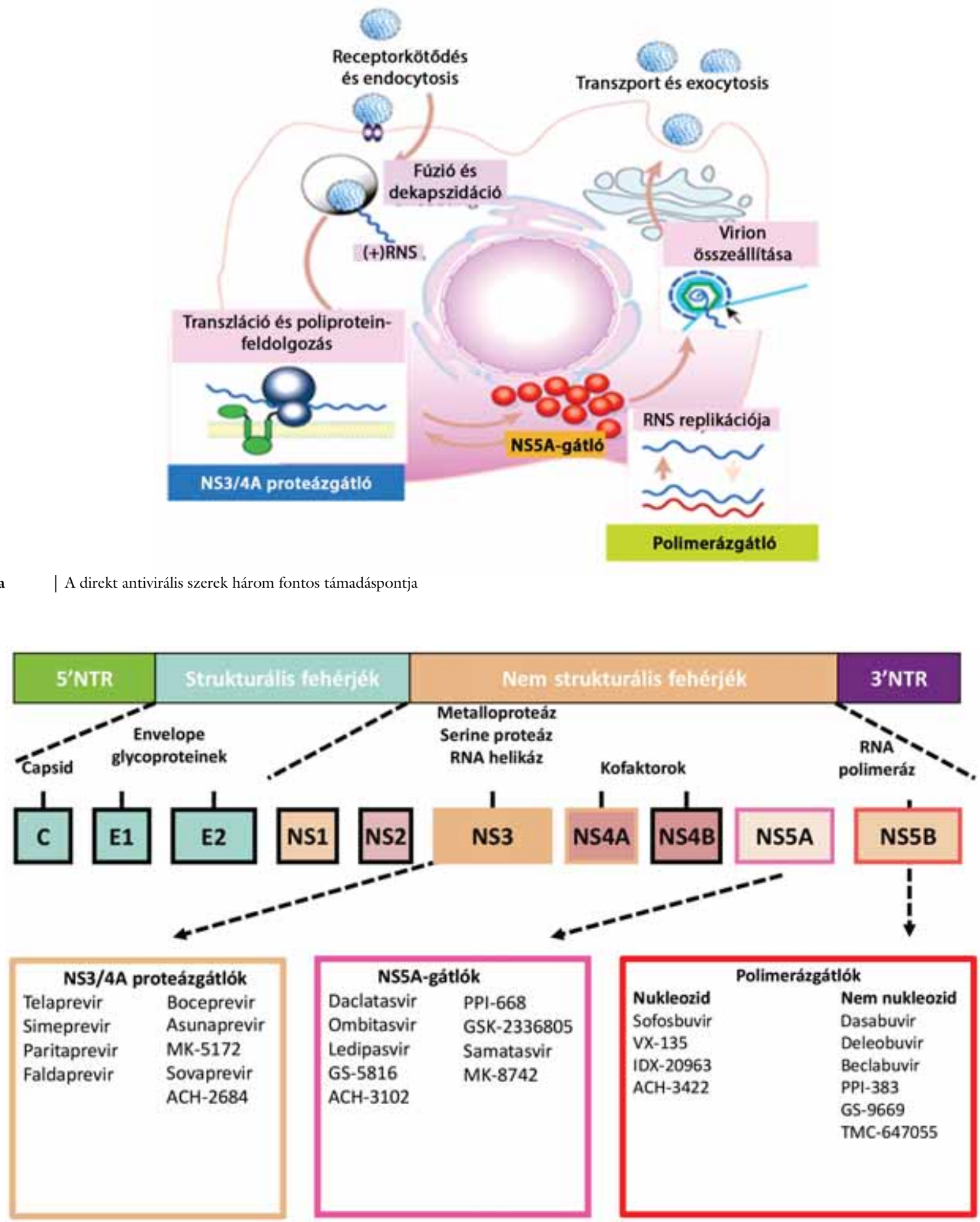

2. ábra

| Forgalomban levő és fejlesztés alatt álló direkt antivirális szerek három kulcsfontosságú virális célpont ellen

A vizsgálatban az la genotípusú fertőzöttek aránya lényegesen magasabb volt (225 versus 56). A betegek 89\%-a gyógyult (SVR), az la genotípus esetében ez $92 \%$, az 1 b genotípus esetében $82 \%$ volt. A cirrhosisos betegek rosszabbul reagáltak $(80 \%)$, mint a kevésbé súlyos fibrosisstádiumúak (92\%) [13]. A kezelés alatti virológiai válasznak nincs prediktív értéke, ezért vizsgálatára nincs szükség. Kedvezőtlen kezelés előtti prediktorok (cirrhosis, nem CC IL28B genotípus, fekete rassz, korábbi IFN-alapú kezelésre nullreagálók) esetében a kezelés 24 hétre történő meghosszabbítása mérlegelhető, bár erre vonatkozó adatok nem állnak rendelkezésre. A korábban sikertelenül kezelt betegek sofosbuvir + peg-IFN + RBV kezeléséről nincsenek adatok, jelenleg alkalmazása ezek- 
ben az esetekben - hasonlóan a kedvezőtlen prediktorokkal rendelkező esetekhez - költséghatékonysági megfontolások alapján mérlegelendő $[1,11]$.

\section{Peg-IFN + RBV + simeprevir}

A QUEST-1 és QUEST-2 fázis III vizsgálatban naiv, l-es genotípusú betegeknek 12 hétig adtak napi $1 \times 150$ mg simeprevirt peg-IFN-nel és RBV-vel kombinálva, amelyet (a 4. heti vírusválasztól függően) további 12 vagy 36 hétig peg-IFN + RBV kettős kezelés követett. lb genotípus esetén 85\%-ban sikerült SVR-t elérni, míg azokban az la genotípussal fertózött betegek esetében, akiknél a kezelés előtt a vírus Q80K-mutációja nem volt kimutatható, $84 \%$ volt az SVR-arány, az e mutációt hordozók esetében csak 58\%. Előrehaladott fibrosis kedvezőtlen prediktornak bizonyult, az SVR-arány METAVIR F3 esetén 73\%, míg F4 esetében $60 \%$ volt [14, 15]. A korábbi kettős kezelésre relapszereket (kedvező IFN-válaszkészséggel rendelkező betegek) a PROMISE vizsgálat keretében kezelték simeprevir + peg-IFN + RBV-vel. Az lb-s betegek 86\%-ában értek el SVR-t, az la genotípus esetében 78\%-ban, ha nem volt jelen a Q80K-mutáció, ellenkező esetben $47 \%$ volt a gyógyulási arány. A korábbi relapszerek esetében a fibrosisstádium jóval kevésbé befolyásolta az SVR-arányt: F0-2: 82\%, F3: 72,7\%, míg F4: 74,4\% [16]. A kettős kombinációra rosszul reagáló (parciális, illetve nullreszponder) betegek simeprevir + peg-IFN + RBV kezelésének eredményei (ATTAIN study) kevésbé meggyőzőek: 69,7\%, illetve 43,6\% SVR [17]. Mindezek alapján a simepreviralapú hármas kombináció naiv és relapszer betegek esetében lehet indokolt. A kezelés 4 . hetére megfelelő vírusválaszt mutató (HCV-RNS <25 IU / ml) betegek esetében - a fibrosisstádiumtól függetlenül - összesen 24 hetes kezelésre van csak szükség. Nem megfelelő 4 . heti vírusválasz esetén a kezelést le kell állítani.

Jelenleg folyik egy klinikai vizsgálat annak igazolására, hogy naiv, nem előrehaladott fibrosisstádiumú (F0-2) betegek esetében elegendő lehet összesen 12 hetes kezelés abban az esetben, ha a beteg már a kezelés 2 . hetére vírus- (HCV-RNS-) negatívvá válik [https://www.clinicaltrials.gov/ct2/show/NCT01846832 ?term=HPC30 $14 \&$ rank=1].

\section{IFN-mentes kezelési lehetóségek HCV 1-es genotipussal fertözött betegek esetén}

\section{Sofosbuvir + simeprevir $\pm \mathrm{RBV}$}

A COSMOS fázis II klinikai vizsgálatban a négy vizsgálati karon a betegek napi $400 \mathrm{mg}$ sofosbuvirt és napi 150 mg simeprevirt \pm RBV-t kaptak 12 , illetve 24 hétig. A vizsgálatba la és lb genotípusú, naiv és korábban kettős kezelésben részesült, cirrhosisos és nem cirrhosisos betegeket vontak be. la genotípus esetén az SVR-t 79,3100\%-ban sikerült elérni. A nem cirrhosisos betegek 12 hetes kezeléssel, RBV nélkül 95\%-ban (20/21) értek el SVR-t, míg a cirrhosisos betegek 86\%-ban (6/7). 24 he- tes kezeléssel minden cirrhosisos beteg gyógyult (10/10). Virológiai sikertelenség 6 esetben fordult elö az la genotípusú betegeknél, közülük 4 esetében lehetett a Q80K-polimorfizmust kimutatni. Ugyanakkor az e mutációval rendelkező betegek esetében is $88 \%$ volt az SVR-arány. Az lb genotípusú betegek esetében virológiai sikertelenség nem fordult elő [18].

Májátültetésen átesett betegek sofosbuvir + simeprevir kezelésével kapcsolatban több prospektív vizsgálat zajlik. Pungpapong és mtsai 2014. decemberben közöltek interim adatokat májátültetésen átesett betegek 12 hetes sofosbuvir + simeprevir + RBV kezeléséről. A vizsgálatba 77 beteget vontak be. 40 beteg közül, aki már $\geq 4$ hétig kapott kezelést, 39 vált vírusnegatívvá, 12 . heti eredménye 22 betegnek volt, valamennyien HCV-negatívak voltak, az utánkövetés 4 . hetéig 12 beteg jutott már el, közülük 11 esetében a HCV-RNS nem volt detektálható [19].

Az amerikai (AASLD) ajánlás minden cirrhosisos beteg esetében 24 hetes kezelést javasolt, míg az európai és a hazai a 12 hetes kezelési időtartam mellett foglal állást, kedvezőtlen prediktorok (la genotípus, cirrhosis, korábbi nullreszponderek) esetén RBV hozzáadásával [1, 11, 12].

\section{Sofosbuvir + daclatasvir \pm RBV}

Napi $400 \mathrm{mg}$ sofosbuvir és $60 \mathrm{mg}$ daclatasvir kombinációja 12 hétig, RBV nélkül is 98\% (40/41) SVR-t eredményezett korábban nem kezelt l-es genotípusú betegek esetében. A korábban sikertelen kettős vagy hármas (telaprevir vagy boceprevir) kezelésben részesült betegek esetében a 24 hetes kezelés RBV-vel 100\%-ban, RBV nélkül 95\%-ban eredményezett gyógyulást [20]. Cirrhosisos és korábbi PI (telaprevir, boceprevir) nem reagáló betegek esetében 24 hetes kezelés ajánlott. RBV hozzáadása nem látszik indokoltnak $[1,11]$.

\section{Sofosbuvir + ledipasvir \pm RBV}

A sofosbuvir (400 mg) és ledipasvir $(90 \mathrm{mg}$ ) kombinációt az ION-I és az ION-III vizsgálatban, összesen 1512 naiv betegnek adták. Az ION-I vizsgálatban a betegek 12 vagy 24 hétig kapták a kombinációt RBV-vel vagy a nélkül. Az SVR-arány 97-99\% volt, függetlenül a genotípustól (la vagy lb), a kezelés időtartamától és az RBV hozzáadásától. A bevont betegek 16\%-a volt cirrhosisos, SVR-arányuk (97\%) nem különbözött a nem cirrhosisos betegekétől (98\%) [21]. Az ION-III vizsgálatban 8, illetve 12 hétig kezelték a betegeket RBV-vel kombinálva vagy a nélkül. Ebben a vizsgálatban cirrhosisos betegek nem szerepeltek. Az SVR-arány 93-95\% között adódott, nem volt különbség a 8 és a 12 hetes kezelési kar között. Az RBV hozzáadása nem befolyásolta a kezelés effektusát [22].

Az ION-II vizsgálatban korábbi peg-IFN + RBV kezelésre nem reagáló betegeket kezeltek 12 , illetve 24 hétig RBV-vel vagy a nélkül. Az SVR-arány 94\%, illetve $96 \%$ volt a 12 hetes, 99-99\% a 24 hetes karokon [23]. 
A SIRIUS vizsgálatban 24 hetes sofosbuvir + ledipasvir kezelés hatékonyságát vetették össze a 12 hetes sofosbuvir + ledipasvir + RBV kezelésével kompenzált cirrhosisos, korábbi peg-IFN + RBV \pm PI kezelésre nem gyógyuló betegek esetében. Az SVR-arány lényegében megegyező volt a két csoportban (96\%, illetve 97\%) [24].

A sofosbuvir + ledipasvir kombináció biztonságos, és eredményesen alkalmazható dekompenzált cirrhosisban (Child B vagy $C$ stádium) is. A SOLAR-II vizsgálatban 108 naiv vagy korábban sikertelenül kezelt 1-es és 4 -es genotípusú beteget kezeltek 12 vagy 24 hétig sofosbuvir + ledipasvir és csökkentett dózisú RBV (600 mg induló dózis) kombinációjával. A 12 hetes karon 87\%, a 24 hetes karon 89\% SVR-t értek el. Relapsus a 12 hetes karon 8\%-ban, a 24 hetes karon 4\%-ban fordult elő. Öt haláleset fordult elő (5\%), egyik sem volt kapcsolatba hozható a kezeléssel. A betegek MELD-score-ja több mint 50\%kal javult. Hármas vagy négyes fokozatú nemkívánatos esemény a 24 hetes karon lényegesen gyakoribb volt (34\% versus 15\%) [12].

A SOLAR-I vizsgálatban 223 májátültetésen átesett, 1-es és 4-es genotípusú beteget kezeltek sofosbuvir + ledipasvir + RBV kombinációval 12, illetve 24 hétig, köztük 51 Child A és 61 Child B és C stádiumú cirrhosisos beteget is. $96 \%$ SVR-t sikerült elérni a nem cirrhosisos és a kompenzált cirrhosisos betegek esetében is, mind a 12 , mind a 24 hetes karon. Child B stádiumú betegek esetében az SVR 85\%, Child C stádiumban $60 \%$ volt. A 24 hetes kezelésnek nem volt bizonyítható előnye, azonban, ha a beteg nem kaphat RBV-t, 24 hetes sofosbuvir + ledipasvir kezelés ajánlható $[12,25] .12$ hetes sofosbuvir + ledipasvir + RBV terápiával a korábban sofosbuvirt tartalmazó más kombinációval sikertelenül kezelt 1-es genotípusú betegek esetében is 100\%-os SVR-t lehetett elérni [26].

A hazai ajánlás szerint naiv, nem cirrhosisos betegek esetében a sofosbuvir + ledipasvir kezelés ajánlott időtartama 8 hét, cirrhosisos esetben 12 hét. Korábban sikertelenül kezelt, nem cirrhosisos betegek esetében 12 hét, cirrhosis egyidejü fennállása esetén 24 hét vagy 12 hét RBV hozzáadásával.

\section{Ombitasvir/paritaprevir/ritonavir + dasabuvir $(\mathrm{ABT} 3 \mathrm{D}) \pm \mathrm{RBV}$}

A 12 hetes ABT3D-kezelés (napi egyszer $150 \mathrm{mg} / 100$ $\mathrm{mg} / 25 \mathrm{mg}$ paritaprevir/ritonavir/ombitasvir és napi kétszer $250 \mathrm{mg}$ dasabuvir) RBV-vel együtt adva l-es genotípusú, naiv, nem cirrhosisos betegeken (SAPPHIRE-I) 96,4\% SVR-t eredményezett (la genotípusban 95,3\%, lb-ben $98,0 \%)$. A virológiai válasz független volt a nemtôl, rassztól, a fibrosisstádiumtól és a kiindulási vírusszámtól is [27].

A PEARL-III és -IV vizsgálatban la és lb genotípusú, naiv, nem cirrhosisos betegeken vizsgálták a 12 hetes $\mathrm{ABT} 3 \mathrm{D} \pm \mathrm{RBV}$ kezelés hatékonyságát. lb genotípusban RBV nélkül 100\% (209/209) SVR-t értek el (RBV-vel együtt adva SVR: 99,5\%), míg la genotípusban RBV nélkül az SVR-arány kissé alacsonyabbnak bizonyult $(90,2 \%$ versus $97 \%)$ [28].

Korábban peg-IFN + RBV-vel sikertelenül kezelt, nem cirrhosisos betegek 12 hetes ABT3D + RBV kezelésével 96,3\% SVR-t értek el (1a: 96,0\%, lb: 96,7\%) [29].

Az lb genotípusú, korábban sikertelenül kezelt, nem cirrhoticus betegek esetében a 12 hetes ABT3D RBV nélkül is (PEARL-II) 100\% SVR-t eredményezett [30].

A TURQUOISE-II vizsgálatban naiv és korábban sikertelenül kezelt, cirrhosisos betegeket kezeltek ABT3D + RBV kombinációval 12 vagy 24 hétig. Az SVR a 12 hetes karon 91,8\%, a 24 hetes karon 96,5\% volt. 1b genotípus esetén a hosszabb kezelés nem javított az eredményeken: $98,5 \%$ versus $100 \%$, míg la genotípus esetén e betegcsoportban a 24 hetes kezelés nagyobb SVRarányt eredményezett: $88,6 \%$ versus 95,0\% [31].

A CORAL-I vizsgálatban 34, májtranszplantáción átesett beteget kezeltek 24 hétig ABT3D + RBV-vel, 33 beteg ért el SVR-t (97\%) [32]. Az ABT3D-kezelés 1b genotípusú, nem cirrhosisos betegek esetében 12 hét RBV nélkül. lb genotípusú cirrhosisos és la genotípusú nem cirrhosisos betegnek 12 hét RBV-vel, la genotípusú cirrhosisos betegeknek 24 hét RBV-vel. Alkalmazásáról Child $\mathrm{B}$ stádiumban nincs adat, Child $\mathrm{C}$ stádiumban ellenjavallt. Korábbi, első generációs PI (boceprevir, telaprevir) alapú hármas kezelésre nem gyógyuló betegek esetében az ABT3D-kezelés nem ellenjavallt, de hatékonyságát nem vizsgálták.

\section{Simeprevir + daclatasvir}

A simeprevir + daclatasvir kezelésnek lb genotípussal fertőzött betegek kezelésében lehet szerepe. A LEAGUE-I vizsgálatban 147 lb genotípusú, naiv (104) vagy korábbi kezelésre nullreszponder (43) beteget kezeltek 12 vagy 24 hétig napi $30 \mathrm{mg}$ daclatasvir és $150 \mathrm{mg}$ simeprevir kombinációjával $\pm \mathrm{RBV}$-vel. A hármas kombinációt kapó betegek 75\%-a, míg az RBV nélküli karokon levő betegek $85 \%$-a volt vírusnegatív a kezelés befejezése utáni 12. héten [33]. Az alacsony daclatasvirdózisnak (napi $30 \mathrm{mg}$, szemben a ma már általánosan használt napi $60 \mathrm{mg}$-mal) szerepe lehetett a relatív alacsonyabb hatékonyságban. Emiatt a jelenleg zajló COMMIT vizsgálatban a 12 hetes daclatasvir (napi $60 \mathrm{mg}$ ) és simeprevir (napi $150 \mathrm{mg}$ ) kombináció hatásosságát és biztonságosságát vizsgálják olyan $1 \mathrm{~b}$ genotípusú betegekben, akikben a HCV NS5A-L31M/V és NS5A-Y93H polimorfizmus nem mutatható ki [https://www.clinicaltrialsregister.eu/ctr-search/trial/2014-003413-28/HU].

\section{Asunaprevir + daclatasvir}

Az asunaprevir csak Japánban törzskönyvezett készítmény, az Európai Unióban nem. A HALLMARK-DUAL fázis III vizsgálatban, amelyben európai vizsgálóhelyek is részt vettek, naiv (307), korábbi kezelésre nem reagáló (205) és IFN-kezelésre nem alkalmas (235) betegeket 
1. táblázat | Törzskönyvezett interferonmentes kombinációk alkalmazása hepatitis C-vírus lb genotípus okozta krónikus C hepatitis kezelésére

\begin{tabular}{|c|c|c|c|c|}
\hline \multirow[t]{2}{*}{ Gyógyszerek } & \multicolumn{2}{|l|}{ Naiv } & \multicolumn{2}{|l|}{ Ismételt kezelés } \\
\hline & Nincs cirrhosis & Cirrhosis & Nincs cirrhosis & Cirrhosis \\
\hline Sofosbuvir + simeprevir & 12 hét & 12 hét + RBV & $\begin{array}{l}12 \text { hét, ha nullreszponder } \\
+\mathrm{RBV}\end{array}$ & 12 hét $+\mathrm{RBV}$ \\
\hline Sofosbuvir + daclatasvir & 12 hét & 24 hét & $\begin{array}{l}12 \text { hét, } \\
\text { ha PI failure } 24 \text { hét }\end{array}$ & 24 hét \\
\hline Sofosbuvir + ledipasvir & 8 hét* & 12 hét & 12 hét & 12 hét + RBV \\
\hline ABT3D & 12 hét & 12 hét + RBV & 12 hét & 12 hét + RBV \\
\hline
\end{tabular}

ABT3D = ombitasvir/paritaprevir/ritonavir + dasabuvir hármas kombináció; PI = proteázgátló; RBV = ribavirin

${ }^{*} \mathrm{Ha}$ a vírustiter $<6000000 \mathrm{IV} / \mathrm{ml}$, ha e felett van: 12 hét.

2. táblázat | Törzskönyvezett interferonmentes kombinációk alkalmazása hepatitis C-vírus la genotípus okozta krónikus C hepatitis kezelésére

\begin{tabular}{lll|ll}
\hline Gyógyszerek & Naiv & Ismételt kezelés & \\
\cline { 2 - 5 } & Nincs cirrhosis & Cirrhosis & Nincs cirrhosis & Cirrhosis \\
\hline Sofosbuvir + simeprevir & 12 hét + RBV & 12 hét + RBV & 12 hét + RBV & 12 hét + RBV \\
Sofosbuvir + daclatasvir & 12 hét & 24 hét & $\begin{array}{l}12 \text { hét, } \\
\text { ha PI failure 24 hét }\end{array}$ & 24 hét \\
Sofosbuvir + ledipasvir & 8 hét* $^{*}$ & 12 hét & 12 hét & 12 hét + RBV \\
ABT3D & 12 hét + RBV & 12 hét + RBV & RBV & 24 hét + RBV \\
\hline
\end{tabular}

ABT3D = ombitasvir/paritaprevir/ritonavir + dasabuvir hármas kombináció; PI = proteázgátló; RBV = ribavirin .

* Ha a vírustiter <6 $000000 \mathrm{IV} / \mathrm{ml}$, ha e felett van: 12 hét.

kezeltek 24 hétig napi $100 \mathrm{mg}$ asunaprevir és napi $60 \mathrm{mg}$ daclatasvir kombinációval. A naiv betegek 90\%-a, a korábbi nem reagálók és az IFN-kezelésre alkalmatlanok 82-82\%-a ért el SVR-t [34]. Az asunaprevir + daclatasvir 24 hetes kezelés olyan 1 b genotípusú betegek esetében lehet terápiás alternatíva, akik nem hordozzák az NS5AL31M/V és az NS5A-Y93H rezisztencia asszociálta variánst.

A törzskönyvezett IFN-mentes kombinációkat lb és la genotípus esetén az 1 . és 2. táblázatban foglaltuk össze.

A kezelés alatti virológiai válasznak az SVR vonatkozásában nincs prediktív értéke, de az adherencia, a kezelés hatásossága, és az esetleges rezisztencia megítélésére a kezelés 2 . és/vagy 4 . hetében vizsgálata ajánlott.

\section{Következtetések}

$\mathrm{Az}$ új generációs DAA-k megjelenése alapvetően változtatta meg a CHC kezelési stratégiáját, a betegség megítélését. A ma rendelkezésre álló kezelési lehetőségek közel 100\%-os eredményességet, vírusmentességet tesznek lehetővé. Olyan betegek esetében is lehetségessé válik a vírus eradikációja, akiket korábban sikertelenül kezeltünk, illetve azok számára is, akiknél a betegség súlyossága, az IFN és/vagy az RBV ellenjavallata vagy egyéb okok miatt eddig semmiféle antivirális kezelésre nem volt mód. Mindez a korábbi kezelésekhez képest lényegesen rövidebb idejű (jellemzően 12 hétig tartó), kényelmesebb (csak szájon át szedendő gyógyszerekkel) és biztonságosabb, minimális mellékhatásokkal járó kezeléssel elérhető. A CHC kezelése ma már nem is annyira szakmai, mint sokkal inkább szervezési és gazdasági kérdés. A panasz- és gyakran tünetmentes fertőzöttek megtalálása feltétele annak, hogy meggyógyíthassuk őket. Azokat a betegeket is el kell érnünk, akik tudnak HCV-fertőzésükről, betegségükről, de sok éve úgy élnek korábbi - téves - információk alapján, hogy őket nem kell kezelni, mert „nem betegek, csak vírushordozók”, vagy nem lehet kezelni őket, mert „ez egy gyógyíthatatlan, halálos betegség”. Fontos, hogy még súlyos májkárosodás, előrehaladott cirrhosis esetében is tisztázzuk az etiológiát, mivel az oki kezelés ma már ilyen esetekben is lehetséges, indokolt és jelentős javulást hozhat.

Fontos leszögezni, hogy kizárólag szakmai szempontokat figyelembe véve a májkárosodás súlyosságától függetlenül minden HCV-fertőzött beteg antivirális kezelése indokolt (vagy legalábbis mérlegelendő), továbbá, hogy hatékonyságuk és biztonságosságuk miatt valamennyi, kezelésre szoruló betegnél egyértelmüen előnyben részesítendők az IFN-mentes kezelések. Az Európában törzskönyvezett készítmények közül a magyar betegek számára jelenleg a legelőnyösebbnek a sofosbuvir + ledipasvir és - megfelelő betegcsoportokban - az ABT3D kombináció látszik. A HCV felismerésének és kezelésének jelenleg csak finanszírozási korlátai vannak, 
de az egyre élesedő piaci verseny - amelyet remélhetően a még újabb készítmények közeljövőben várható törzskönyvezése csak fokozni fog - az árak további, egyre gyorsabb és jelentősebb csökkenéséhez vezet, így a betegek mind szélesebb köre számára válhat elérhetővé a gyógyulás. Ma már a HCV teljes eradikációja sem utópia, ehhez azonban a hatékony terápián kívül elengedhetetlen valamennyi HCV-fertőzött fellelése, amely jól megtervezett, megszervezett és finanszírozott(!) szûrőprogramok nélkül nem lehetséges.

Anyagi támogatás: A cikk megírása anyagi támogatásban nem részesült.

Szerzői munkamegosztás: A kézirat megszövegezésében H. G., H. T. előkészítő munkáját követően, a társszerzők egyenlő arányban vettek részt. A kézirat végleges változatát valamennyi szerző elolvasta és jóváhagyta.

Érdekeltségek: H. G.: Előadói/tanácsadói díjban és/vagy kutatási támogatásban részesült az alábbi gyógyszer előállítóktól/forgalmazóktól: AbbVie Kft., Boehringer Ingelheim, Bristol-Myers Squibb Kft., Fresenius-Kabi, Gilead Sciences, Janssen Cilag Kft., MSD Pharma Hungary Kft., Merck Kft., Roche Magyarország Kft. M. M.: Elöadói/tanácsadói díjban és/vagy kutatási támogatásban részesült az alábbi gyógyszer előállítóktól/forgalmazóktól: AbbVie Kft., Boehringer Ingelheim, Bristol-Myers Squibb Kft., Fresenius-Kabi, Gilead Sciences, Janssen Cilag Kft., MSD Pharma Hungary Kft., Merck Kft., Roche Magyarország Kft. H. B.: Előadói/tanácsadói díjban és/vagy kutatási támogatásban részesült az alábbi gyógyszer előállítóktól/forgalmazóktól: AbbVie Kft., Boehringer Ingelheim, Bristol-Myers Squibb Kft., FreseniusKabi, Gilead Sciences, Janssen Cilag Kft., MSD Pharma Hungary Kft., Merck Kft., Roche Magyarország Kft.

\section{Irodalom}

[1] Hunyady, B., Gerlei, Zs., Gervain, J., et al.: Diagnosis, treatment, and follow-up of hepatitis $\mathrm{C}$ virus related liver disease. Hungarian national consensus guideline. [Hepatitis C-vírus-fertőzés: diagnosztika, antivirális terápia, kezelés utáni gondozás. Magyar konszenzusajánlás.] Orv. Hetil., 2015, 156(Suppl. 1), 3-23. [Hungarian]

[2] Van der Meer, A. J., Veldt, B. J., Feld, J. J., et al.: Association between sustained virological response and all-cause mortality among patients with chronic hepatitis $\mathrm{C}$ and advanced hepatic fibrosis. JAMA, 2012, 308(24), 2584-2593.

[3] Barna, T. K., Ozsvár, Z., Szendrényi, V., et al.: Hepatitis C virus antibody in the serum of blood donors. [Hepatitis C-vírus ellenanyag előfordulása véradók szérumában.] Orv. Hetil., 1996, 137(10), 507-511. [Hungarian]

[4] Bacon, B. R., Gordon, S. C., Lawitz, E., et al.: Boceprevir for previously treated chronic HCV genotype 1 infection. N. Engl. J. Med., 2011, 364(13), 1207-1217.

[5] Jacobson, I. M., McHutchison, J. G., Dusheiko, G., et al.: Telaprevir for previously untreated chronic hepatitis $\mathrm{C}$ virus infection. $\mathrm{N}$. Engl. J. Med., 2011, 364(25), 2405-2416.
[6] Poordad, F., McCone, J. Jr., Bacon, B. R., et al.: Boceprevir for untreated chronic HCV genotype 1 infection. N. Engl. J. Med., 2011, 364(13), 1195-1206.

[7] Zeuzem, S., Andreone, P., Pol, S., et al.: Telaprevir for retreatment of HCV infection. N. Engl. J. Med., 2011, 364(25), 2417-2428.

[8] Hézode, C., Fontaine, H., Dorival, C., et al.: Triple therapy in treatment-experienced patients with $\mathrm{HCV}$-cirrhosis in a multicentre cohort of the French Early Access Programme (ANRS CO20-CUPIC) - NCT01514890. J. Hepatol., 2013, 59(3), 434-441.

[9] Schinazi, R., Halfon, P., Marcellin, P., et al.: HCV direct-acting antiviral agents: the best interferon-free combinations. Liver Int., 2014, 34(Suppl. 1), 69-78.

[10] Gervain, J., Simon, G. Jr., Papp, I., et al.: Analysing the type and subtype of hepatitis virus $\mathrm{C}$ of chronic viral hepatitis patients in Hungary. [A magyarországi krónikus „C” vírushepatitises betegek vírustípus- és szubtípus-meghatározása.] Orv. Hetil., 2001, 142(25), 1315-1319. [Hungarian]

[11] EASL: EASL recommendations on treatment of hepatitis C. http://www.easl.eu/research/our-contributions/clinical-practice-guidelines/detail/recommendations-on-treatment-of-hepatitis-c-2015/report/1

[12] AASLD: Recommendations for testing, managing and treating hepatitis C. http://www.hcvguidelines.org/full-report-view

[13] Lawitz, E., Mangia, A., Wyles, D., et al.: Sofosbuvir for previously untreated chronic hepatitis C infection. N. Engl. J. Med., 2013, 368(20), 1878-1887.

[14] Jacobson, I., Dore, G. J., Foster, G. R., et al.: Simeprevir (TMC435) with peginterferon/ribavirin for chronic HCV genotype- 1 infection in treatment-naive patients: results from QUEST-1, a Phase III trial. J. Hepatol., 2013, 58(Suppl. 1), S574.

[15] Manns, M., Marcellin, P., Poordad, F., et al.: Simeprevir (TMC435) with peginterferon/ribavirin for treatment of chronic HCV genotype-1 infection in treatment-naive patients: results from QUEST-2, a Phase III trial. J. Hepatol., 2013, 58(Suppl. 1), 5568

[16] Lawitz, E., Forns, X., Zeuzem, S., et al.: Simeprevir (TMC435) with peginterferon/ribavirin for treatment of chronic $\mathrm{HCV}$ genotype 1 infection in patients who relapsed after previous interferonbased therapy: results from PROMISE, a Phase III trial. Gastroenterology, 2013, 144, S151.

[17] Reddy, K. R., Zeuzem, S., Zoulim, F., et al.: A Phase III randomised, double-blind study to evaluate the efficacy, safety and tolerability of simeprevir vs telaprevir in combination with pegylated interferon and ribavirin in chronic hepatitis $\mathrm{C}$ virus genotype 1 treatment-experienced patients: the ATTAIN study. http://www.natap.org/2014/APASL/APASL_20.htm

[18] Lawitz, E., Sulkowski, M. S., Ghalib, R., et al.: Simeprevir plus sofosbuvir, with or without ribavirin, to treat chronic infection with hepatitis $\mathrm{C}$ virus genotype 1 in non-responders to pegylated interferon and ribavirin and treatment-naive patients: the COSMOS randomised study. Lancet, 2014, 384(9956), 17561765.

[19] Pungpapong, S. K., Werner, K. T., Aqel, B., et al.: Multicenter experience using sofosbuvir and simeprevir with/without ribavirin to treat $\mathrm{HCV}$ genotype 1 after liver transplantation. Hepatology, 2014, 60(Suppl. 4), 201A.

[20] Sulkowski, M. S., Gardiner, D. F., Rodriguez-Torres, M., et al.: Daclatasvir plus sofosbuvir for previously treated or untreated chronic HCV infection. N. Engl. J. Med., 2014, 370(3), 211221.

[21] Afdhal, N., Zeuzem, S., Kwo, P., et al.: Ledipasvir and sofosbuvir for untreated HCV genotype 1 infection. N. Engl. J. Med., 2014, 370(20), 1889-1898.

[22] Kowdley, K. V., Gordon, S. C., Reddy, K. R., et al.: Ledipasvir and sofosbuvir for 8 or 12 weeks for chronic HCV without cirrhosis. N. Engl. J. Med., 2014, 370(20), 1879-1888. 
[23] Afdbal, N., Reddy, K. R., Nelson, D. R., et al.: Ledipasvir and sofosbuvir for previously treated HCV genotype 1 infection. N. Engl. J. Med., 2014, 370(16), 1483-1493.

[24] Bourliere, M., Bronowicki, J. P., de Ledinghen, V., et al.: Ledipasvir/sofosbuvir fixed-dose combination is safe and efficacious in cirrhotic patients who have previously failed protease-inhibitor based triple therapy. http://www.natap.org/2014/AASLD/ AASLD_20.htm

[25] Reedy, K. R., Everson, G. T., Flamm, S. L., et al.: Ledipasvir/sofosbuvir with ribavirin for the treatment of $\mathrm{HCV}$ in patients with post transplant recurrence: Preliminary results of a prospective, multicenter study. Hepatology, 2014, 60(Suppl. 4), 200A.

[26] Wyles, D., Pockros, P., Zhu, Y., et al.: Retreatment of patients who failed prior sofosbuvir-based regimens with all oral fixed-dose combination ledipasvir/sofosbuvir plus ribavirin for 12 weeks. http://www.natap.org/2014/AASLD/AASLD_72.htm

[27] Feld, J. J., Kowdley, K. V., Coakley, E., et al.: Treatment of HCV with ABT-450/r-ombitasvir and dasabuvir with ribavirin. $\mathrm{N}$. Engl. J. Med., 2014, 370(17), 1594-1603.

[28] Ferenci, P., Bernstein, D., Lalezari, J., etal.:ABT-450/r-ombitasvir and dasabuvir with or without ribavirin for HCV. N. Engl. J. Med., 2014, 370(21), 1983-1992.

[29] Zeuzem, S., Jacobson, I. M., Baykal, T., et al.: Retreatment of $\mathrm{HCV}$ with ABT-450/r-Ombitasvir and Dasabuvir with Ribavirin. N. Engl. J. Med., 2014, 370(17), 1604-1614.

[30] Andreone, P., Colombo, M. G., Enejosa, J. V., et al.: ABT-450, ritonavir, ombitasvir, and dasabuvir achieves $97 \%$ and $100 \%$ sus- tained virologic response with or without ribavirin in treatmentexperienced patients with HCV genotype $1 \mathrm{~b}$ infection. Gastroenterology, 2014, 147(2), 359-365.el.

[31] Poordad, F., Hezode, C., Trinh, R., et al.: ABT-450/r-ombitasvir and dasabuvir with ribavirin for hepatitis $\mathrm{C}$ with cirrhosis. N. Engl. J. Med., 2014, 370(21), 1973-1982.

[32] Kwo, P. צ., Mantry, P. S., Coakley, E., et al.: An interferon-free antiviral regimen for HCV after liver transplantation. http:// www.natap.org/2014/AASLD/AASLD_53.htm

[33] Zeuzem, S., Hezode, C., Bronowicki, J. P., et al.: Daclatasvir in combination with simeprevir with or without ribavirin for hepatitis $\mathrm{C}$ virus genotype 1 infection. 21 st Conference on Retroviruses and Opportunistic Infections (CROI 2014). Boston, March 3-6. Abstract 28LB. http://www.hivandhepatitis.com/ hcv-treatment/experimental-hcv-drugs/4577-croi-2014-daclatasvir-simeprevir-effective-against-hepatitis-c-genotype-1b

[34] Manns, M., Pol, S., Jacobson, I. M., et al.: All-oral daclatasvir plus asunaprevir for hepatitis $\mathrm{C}$ virus genotype $\mathrm{lb}$ : a multinational, phase 3, multicohort study. Lancet, 2014, 384(9954), 15971605 .

(Horváth Gábor dr., Budapest, Egry J. u. 1-3. T épület, földszint, 1111 e-mail: horvath.gabor@hepatologia.hu)

\section{Tisztelt Szerzőink, Olvasóink!}

Az Orvosi Hetilapban megjelenő/megjelent közlemények elérhetőségére több lehetőség kínálkozik.

Rendelhető különlenyomat, melynek áráról bővebben a www.akkrt.hu honlapon (Folyóirat Szerzőknek, Különlenyomat menüpont alatt) vagy Szerkesztőségünkben tájékozódhatnak.

A közlemények megvásárolhatók pdf-formátumban is, illetve igényelhető Optional Open Article (www.oopenart.com).

Adott dij ellenében az online közlemények bárki számára hozzáférhetők honlapunkon (a közlemények külön linket kapnak, így más oldalról is linkelhetővé válnak).

Bővebb információ a hirdetes@akkrt.hu címen vagy különlenyomat rendelése esetén a Szerkesztőségtől kérhető. 